\title{
lloprost for pulmonary vasodilator testing in idiopathic pulmonary arterial hypertension
}

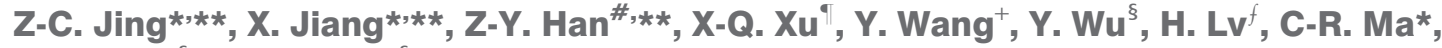 \\ Y-J. Yang ${ }^{\S}$ and J-L. $\mathbf{P u}^{\S}$
}

ABSTRACT: The aim of this study was to confirm the utility of aerosolised iloprost for identifying long-term responders to calcium channel blockers (CCBs) in patients with idiopathic pulmonary arterial hypertension (IPAH).

While undergoing right heart catheterisation, 74 patients with IPAH sequentially received incremental infusions of adenosine and aerosolised iloprost. The effects of the two vasodilators on haemodynamic parameters were recorded. All acute responders identified by aerosolised iloprost were subsequently treated with high doses of a CCB and were re-evaluated after 12 months.

Both adenosine and iloprost produced significant decreases in mean pulmonary arterial pressure and pulmonary vascular resistance, and significant increases in cardiac index. Adverse effects were experienced by 35 out of the 74 patients with adenosine, but by only two with iloprost. Aerosolised iloprost identified more acute responders than infused adenosine (10 versus eight, respectively) according to the criteria recommended in recent consensus guidelines. Nine responders identified by iloprost were followed-up after 12 months of high-dose ССВ therapy. Five had normal or near-normal haemodynamics and a World Health Organization functional classification of I or II after 12 months.

Aerosolised iloprost is an appropriate new agent to identify long-term responders to CCBs in patients with IPAH. It is as effective in this regard as infused adenosine but is better tolerated.

KEYWORDS: Adenosine, calcium channel blockers, iloprost, inhaled therapy, pulmonary arterial hypertension, vasoreactivity testing

diopathic pulmonary arterial hypertension (IPAH) is characterised by progressive increases in pulmonary vascular resistance (PVR) without a demonstrable cause, which eventually lead to right heart dysfunction or even death. Uncontrolled studies have suggested that extended treatment with calcium channel blockers (CCBs) prolongs survival in rare cases of acutely vasoresponsive patients [1, 2].

Recent international consensus statements have recommended vasoreactivity testing as an important component of the evaluation of patients with pulmonary arterial hypertension $(\mathrm{PAH})$, especially those with IPAH $[3,4]$. Currently, three shortacting agents are widely recommended in these guidelines for acute pulmonary vasoreactivity testing: intravenous epoprostenol $[5,6]$, i.v. adenosine $[4,7]$, and inhaled nitric oxide (NO) $[8,9]$. However, both i.v. epoprostenol and i.v. adenosine often cause systemic hypotension and other intolerable adverse effects when their dosages are incrementally increased to higher levels [7, 10, 11]. Inhaled NO has been advocated as an effective way of identifying acute haemodynamic responses but the use of inhaled NO requires complicated administration and monitoring devices, and its acute withdrawal can lead to dangerous rebound pulmonary hypertension $[12,13]$.

Iloprost is a stable, short-acting carbacyclin analogue of prostacyclin (prostaglandin $\mathrm{I}_{2}$ ) with a plasma half-life of $20-30 \mathrm{~min}$. There is considerable evidence to show that aerosolised iloprost is a more potent pulmonary vasodilator than inhaled NO [5, 14, 15], and it has been widely used for pulmonary vasoreactivity testing in many medical centres in the past several years [16]. However, no studies have investigated whether an acute response to iloprost identifies responders to long-term treatment with high doses of CCBs administered for at least 12 months. Therefore, the principal objective of this study was to determine whether aerosolised
AFFILIATIONS

${ }^{*}$ Dept of Pulmonary Circulation,

Shanghai Pulmonary Hospital, Tongji University, Shanghai,

Depts of ${ }^{\#}$ Anaesthesiology and

${ }^{\S}$ Cardiovascular Medicine,

Cardiovascular Institute and Fu Wai

Hospital, Peking Union Medical

College,

"Dept of Internal Medicine, Aviation Industry Central Hospital,

${ }^{+}$Dept of Respiratory Medicine,

Beijing Shijitan Hospital, Peking

University,

${ }^{f}$ Dept of Cardiovascular Medicine,

The Second Hospital of Chinese

Armed Police Forces Beijing City

Corps, Beijing, China

${ }^{\star *}$ All three authors contributed

equally to this article.

\section{CORRESPONDENCE}

Z-C. Jing

Dept of Pulmonary Circulation

Shanghai Pulmonary Hospital

Tongji University

507, Zhengmin Road

Shanghai, 200433, China

Fax: 862155662767

E-mail: jingzhicheng@gmail.com

Received:

November 092008

Accepted after revision:

January 252009

SUPPORT STATEMENT

This study was supported by China National 973 Project (2007

CB512008).

STATEMENT OF INTEREST

None declared.

Online ISSN 1399-3003 
iloprost can be used as an alternative to infused adenosine to identify patients who may be long-term responders to CCBs, via acute pulmonary vasodilator testing of IPAH patients undergoing right heart catheterisation. Adenosine was used as the comparator as it was the only agent among the three standard short-acting standard pulmonary vasodilators available in China when the study was performed.

\section{MATERIALS AND METHODS \\ Patient population}

Between July 2006 and March 2008, 74 patients with IPAH were enrolled consecutively in the study. Patient selection was based upon the following criteria: a diagnosis of IPAH established after exclusion of secondary causes of pulmonary hypertension; a mean pulmonary artery pressure $\left(\bar{P}_{\mathrm{pa}}\right)$ $>30 \mathrm{mmHg}$; symptomatic disease, despite optimised conventional treatment, corresponding to a World Health Organization (WHO) functional classification of II or III; cessation of treatment with oral anticoagulants until the international normalised ratio was $<1.5$ prior to testing; and provision of written informed consent by each patient.

To exclude other forms of pulmonary hypertension, patients underwent scintigraphy and/or spiral computed tomography (to exclude chronic thromboembolic pulmonary hypertension), echocardiography (for congenital heart disease), high-resolution computed tomography (for lung disease), serological testing (for HIV infection/connective tissue disease) and comprehensive pulmonary and liver function studies (for lung or liver disease). In addition to clinical features, evaluations undertaken in all patients included an ECG, chest radiography, Doppler echocardiography, measurement of the 6-min walk distance (6MWD) and measurement of the following specific PAH biochemical indicators: endothelin (ET)-1, brain natriuretic peptide and serum uric acid.

The study protocol was reviewed and approved by the Ethics Committee of Shanghai Pulmonary Hospital, Tongji University (Shanghai, China).

\section{Haemodynamic measurements}

For this study, all patients were admitted to an intensive therapy room at our hospitals. An $8 \mathrm{~F}$ (for adults) or $6 \mathrm{~F}$ (for children) introducer sheet was placed in the right internal jugular vein or the right subclavian vein, and a quadric-lumen 7F (for adults) or 5F (for children) Swan-Ganz catheter (Edwards Lifesciences World Trade Co. Ltd, Irvine, CA, USA) was advanced into the pulmonary artery. Correct positioning of the catheter was verified by chest fluoroscopy. Transducers were positioned at the midaxillary line and zeroed at atmospheric pressure. $\bar{P}$ pa, mean systemic arterial pressure $\left(\bar{P}_{\mathrm{sa}}\right)$, right atrial pressure $\left(P_{\mathrm{ra}}\right)$ and pulmonary capillary wedge pressure $(P$ pcw $)$ were measured at baseline and after vasodilator drug administration. Cardiac output (CO) was measured in triplicate by the thermodilution technique (Edwards Lifesciences World Trade Co. Ltd,) with ice-cold isotonic sodium chloride solution in patients without severe tricuspid insufficiency (40 cases); otherwise, Fick's method was used to measure $\mathrm{CO}$ in patients with severe tricuspid insufficiency (34 cases). The cardiac index (CI) was calculated by dividing $\mathrm{CO}$ by body surface area. Because the $P$ pcw could not be recorded in all patients during the haemodynamic evaluation, total pulmonary resistance (Rtp), rather than pulmonary arterial resistance, was determined and

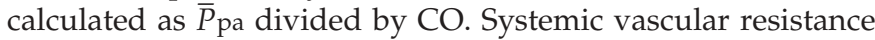
$\left(R\right.$ sv) was calculated as ( $\left.\bar{P}_{\text {sa- }}-P_{\text {ra }}\right)$ divided by $\mathrm{CO}$. The cardiac frequency and the transcutaneous arterial oxygen saturation were monitored continuously.

\section{Vasodilator drug administration}

After baseline haemodynamic parameters had been recorded, adenosine infusions (Ever Bright Pharmaceutical Company, Shenyang, China) were started at a dose of $50 \mu \mathrm{g} \cdot \mathrm{kg}^{-1} \cdot \mathrm{min}^{-1}$ and increased by $50 \mu \mathrm{g} \cdot \mathrm{kg}^{-1} \cdot \mathrm{min}^{-1}$ at 2-min intervals to a maximum dose of $200 \mu \mathrm{g} \cdot \mathrm{kg}^{-1} \cdot \mathrm{min}^{-1}[4,7]$. Haemodynamic parameters and blood gases were monitored during adenosine administration. $30 \mathrm{~min}$ after discontinuation of adenosine, another set of baseline haemodynamic parameters was recorded, and $5 \mu \mathrm{g}$ iloprost (Ventavis ${ }^{\circledR}$; Bayer-Schering Pharma, Berlin, Germany) was delivered by a PARI LC STAR nebuliser (PARI GmbH, Starnberg, Germany) driven by a PARI TurboBOY-N compressor (PARI GmbH) for $\sim 15$ min. This combination produced aerosolised particles with a mass median aerodynamic diameter of $2.2 \mu \mathrm{m}$ and a mass fraction $<5 \mu \mathrm{m}$ of $89 \%$. Another complete set of haemodynamic measurements and blood gases was obtained at the end of inhalation. Any adverse events that occurred during administration of the vasodilator drugs were recorded.

\section{Acute vasoreactivity responses}

A positive acute response in this study was defined in accordance with the recent consensus statements of the American College of Chest Physicians [3] and the European Society of Cardiology [4] as a fall in $\bar{P}$ pa of $\geqslant 10 \mathrm{mmHg}$ to $\leqslant 40 \mathrm{mmHg}$, with an increased or unchanged CO.

\section{Follow-up}

All acute responders identified by iloprost or adenosine were treated with high-dose CCB therapy. Their clinical features were re-evaluated at 6-month intervals and haemodynamic parameters were measured via repeated right heart catheterisation at 12 months.

\section{Statistical analysis}

Haemodynamic parameters were expressed as mean \pm SD. SPSS 13.0 software (SPSS Inc, Chicago, IL, USA) was used for statistical analysis. A paired t-test was applied to compare the baseline and post-treatment differences for adenosine infusion and iloprost inhalation. Differences in haemodynamic changes between adenosine and iloprost were compared via an independent $\mathrm{t}$-test, and this test was also applied to compare differences in clinical features and haemodynamic parameters between acute responders and nonresponders. A Chi-squared test was used to compare differences in WHO functional class and sex distribution between responders and nonresponders. Correlations of haemodynamic changes between adenosine and iloprost were tested via a Spearman's correlation test. A pvalue $<0.05$ was considered significant.

\section{RESULTS}

\section{Patient population}

A total of 74 patients (58 females and 16 males) with IPAH were enrolled in the study. The mean \pm SD (range) age of the patients 
was $33 \pm 12$ (7-66) yrs; seven children were among the patients studied (age ranged 7-17 yrs). 35 patients had a WHO functional class II assessment and 39 had a WHO functional class III assessment. In all patients, the resting $\bar{P}_{\text {pa }}$ was abnormally high (mean \pm SD (range) $60.1 \pm 17.6$ (35-103) $\mathrm{mmHg}$ ) and there was also a marked elevation of $R_{\mathrm{tp}}(17.3 \pm 9.7$ (3.154.4) Wood U). The baseline clinical features and haemodynamic variables of the patient population studied are shown in table 1.

\section{Haemodynamic responses}

The changes of haemodynamic parameters (i.e. maximal changes recorded during administration of the vasodilators) and oxygenation status during adenosine infusion and iloprost inhalation are shown in table 2 and figure 1. During adenosine infusion, $\bar{P}$ pa and $R_{\text {tp }}$ were both significantly reduced from $61.1 \pm 17.6$ to $55.2 \pm 19.4 \mathrm{mmHg}(\mathrm{p}<0.001)$ and from $17.5 \pm 9.8$ to $14.4 \pm 9.4$ Wood $\mathrm{U}(\mathrm{p}<0.001)$, respectively. The $\mathrm{CI}$ and mixed venous oxygen saturation $\left(\mathrm{Sv}, \mathrm{O}_{2}\right)$ were significantly increased from $2.7 \pm 1.1$ to $3.1 \pm 1.4 \mathrm{~L} \cdot \mathrm{min}^{-1} \cdot \mathrm{m}^{-2} \quad(\mathrm{p}<0.001)$ and from $60.8 \pm 13.4 \%$ to $68.5 \pm 12.8 \%(p<0.01)$, respectively, while the $\bar{P}_{\text {sa }}$ and $R_{\text {sv }}$ were significantly decreased from $83.8 \pm 11.7$ to $81.7 \pm 10.5 \mathrm{mmHg} \quad(\mathrm{p}=0.013)$ and from $21.5 \pm 8.8$ to $18.8 \pm 8.7$ Wood $\mathrm{U}(\mathrm{p}<0.001)$, respectively.

Aerosolised iloprost produced a marked decline of both $\bar{P}_{\text {pa }}$ and Rtp from $60.5 \pm 18.9$ to $54.8 \pm 20.9 \mathrm{mmHg}(\mathrm{p}<0.001)$ and from $16.7 \pm 9.4$ to $13.5 \pm 8.2$ Wood $\mathrm{U}(\mathrm{p}<0.001)$, respectively. Iloprost also significantly increased $\mathrm{CI}$ and $\mathrm{S}_{\mathrm{v}, \mathrm{O}_{2}}$ from $2.8 \pm 1.06$ to $3.1 \pm 1.0 \mathrm{~L} \cdot \mathrm{min}^{-1} \cdot \mathrm{m}^{-2}(\mathrm{p}<0.001)$ and from $62.0 \pm 12.3 \%$ to $66.0 \pm 10.8 \%(\mathrm{p}<0.001)$, respectively, and decreased $\overline{\bar{P}}_{\text {sa }}$ and $R$ sv from $82.0 \pm 10.5$ to $79.1 \pm 10.9 \mathrm{mmHg}(\mathrm{p}<0.005)$ and from $20.0 \pm 7.5$ to $17.2 \pm 6.5$ Wood $U(p<0.001)$, respectively.

The haemodynamic changes occurring with iloprost inhalation were comparable to those occurring with adenosine infusion and, with the exception of changes in $S_{\mathrm{v}}, \mathrm{O}_{2}$, there were no significant differences among any of the measured variables. Strong correlations were found for the changes of $\bar{P}_{\mathrm{pa}}(\mathrm{r}=0.798$; $\mathrm{p}<0.001)$ and $R \operatorname{tp}(\mathrm{r}=0.405 ; \mathrm{p}=0.004)$ between iloprost and adenosine.

\section{Acute vasoreactivity responses}

In accordance with the recommended acute response criteria, $10(13.5 \%)$ out of the 74 patients were identified as responders with iloprost and eight $(10.8 \%)$ were responders with adenosine. None of the patients who failed to show an acute response with iloprost inhalation (nonresponders) showed a positive response to adenosine infusion.

A comparison of the baseline clinical characteristics and haemodynamic variables between acute responders and nonresponders to iloprost is shown in table 1 . In contrast to

TABLE 1 Clinical characteristics and baseline haemodynamic parameters of the patients studied

\begin{tabular}{|c|c|c|c|c|}
\hline Parameter & Total & Responders to iloprost & Nonresponders to iloprost & $\mathrm{p}$-value \\
\hline Subjects $n$ & 74 & 10 & 64 & \\
\hline Age yrs & $33.2 \pm 12.1$ & $22.6 \pm 9.1$ & $34.5 \pm 11.8$ & 0.008 \\
\hline Male/female $\mathrm{n}$ & $16 / 58$ & $3 / 7$ & $13 / 51$ & 0.554 \\
\hline WHO class $\|/\| I n$ & $35 / 39$ & $9 / 1$ & $26 / 38$ & 0.002 \\
\hline $\mathrm{Sv}, \mathrm{O}_{2} \%$ & $62.0 \pm 12.3$ & $73.5 \pm 9.4$ & $60.7 \pm 12.0$ & 0.008 \\
\hline $6 M W D \mathrm{~m}$ & $390 \pm 106$ & $438 \pm 80$ & $384 \pm 108$ & 0.178 \\
\hline \multicolumn{5}{|c|}{ Biochemical indicators } \\
\hline $\mathrm{UA} \mu \mathrm{mol} \cdot \mathrm{L}^{-1}$ & $356 \pm 110$ & $323 \pm 50$ & $359 \pm 114$ & 0.419 \\
\hline $\mathrm{ET}-1 \mathrm{fmol} \cdot \mathrm{L}^{-1}$ & $1.0 \pm 0.6$ & $0.6 \pm 0.2$ & $1.0 \pm 0.6$ & $<0.001$ \\
\hline $\mathrm{BNP} \mathrm{fmol} \cdot \mathrm{L}^{-1}$ & $1273 \pm 1137$ & $718 \pm 310$ & $1333 \pm 1178$ & 0.175 \\
\hline $\bar{P}_{\text {pa }} \mathrm{mmHg}$ & $61.1 \pm 17.6$ & $48.4 \pm 10.5$ & $62.6 \pm 17.7$ & 0.029 \\
\hline $\bar{P}_{\text {sa }} \mathrm{mmHg}$ & $83.8 \pm 11.7$ & $77.6 \pm 5.2$ & $84.6 \pm 12.1$ & 0.115 \\
\hline Pra $\mathrm{mmHg}$ & $5.3 \pm 5.1$ & $3.1 \pm 1.9$ & $6.8 \pm 5.6$ & 0.001 \\
\hline Rtp Wood U & $17.3 \pm 9.7$ & $11.4 \pm 5.8$ & $18.0 \pm 9.9$ & 0.088 \\
\hline Rsv Wood U & $21.4 \pm 8.8$ & $16.7 \pm 5.0$ & $21.9 \pm 9.0$ & 0.139 \\
\hline $\mathrm{Cl} \mathrm{L} \cdot \mathrm{min}^{-1} \cdot \mathrm{m}^{-2}$ & $2.6 \pm 1.2$ & $2.9 \pm 1.4$ & $2.6 \pm 1.2$ & 0.439 \\
\hline
\end{tabular}

Data are presented as mean $\pm \mathrm{SD}$, unless otherwise stated. WHO: World Health Organization; BSA: body surface area; $\mathrm{Sa}, \mathrm{O}_{2}$ : arterial oxygen saturation; $\mathrm{Sv}, \mathrm{O}_{2}$ : mixed venous oxygen saturation; 6MWD: 6-min walk distance; UA: uric acid; ET: endothelin; BNP: brain natriuretic peptide; fC: cardiac frequency; Ppcw: pulmonary capillary wedge pressure; $\bar{P}$ pa: mean pulmonary arterial pressure; $\bar{P}$ sa: mean systemic arterial pressure; Pra: right arterial pressure; $R$ tp: total pulmonary resistance; $R$ sv: systemic vascular resistance; $\mathrm{Cl}$ : cardiac index. ${ }^{\#}:$ P pcw could not be successfully measured in eight patients at the first evaluation because of a markedly enlarged right atrium and severe tricuspid regurgitation, but these eight patients were identified as having a $P$ pcw $<15 \mathrm{mmHg}$ on repeated right heart catheterisation with the aid of a guidewire with a diameter of 0.025 inches (Cordis Co., Ltd, Johnson \& Johnson, Miami Lakes, FL, USA) 6-12 months later. 


\begin{tabular}{|c|c|c|c|c|}
\hline TABLE 2 & $\begin{array}{l}\text { Haemodyn } \\
\text { baseline ar } \\
\text { and aerosc }\end{array}$ & $\begin{array}{l}\text { ic variables } \\
\text { in response } \\
\text { ed iloprost }\end{array}$ & $\begin{array}{l}\text { and blood } \\
\text { to infused }\end{array}$ & $\begin{array}{l}\text { gases at } \\
\text { adenosine }\end{array}$ \\
\hline \multirow[t]{2}{*}{ Parameter } & \multicolumn{2}{|c|}{ Adenosine $^{\#}$} & \multicolumn{2}{|c|}{ lloprost } \\
\hline & Baseline & $\begin{array}{c}\text { During } \\
\text { infusion }\end{array}$ & Baseline & $\begin{array}{c}\text { During } \\
\text { inhalation }\end{array}$ \\
\hline fc beats $\mathrm{min}^{-1}$ & $87.3 \pm 14.2$ & $87.3 \pm 12.6$ & $87.3 \pm 14.1$ & $87.6 \pm 12.2$ \\
\hline $\bar{P}_{\text {pa }} \mathbf{m m H g}$ & $61.1 \pm 17.6$ & $55.2 \pm 19.4^{+}$ & $60.5 \pm 18.9$ & $54.8 \pm 20.9^{+}$ \\
\hline $\bar{P}_{\text {sa }} \mathbf{m m H g}$ & $83.8 \pm 11.7$ & $81.7 \pm 10.5^{+}$ & $82.0 \pm 10.5$ & $79.1 \pm 10.9^{+}$ \\
\hline Rtp Wood U & $17.5 \pm 9.8$ & $14.4 \pm 9.4^{+}$ & $16.7 \pm 9.4$ & $13.5 \pm 8.2^{+}$ \\
\hline Rsv Wood U & $21.5 \pm 8.8$ & $18.8 \pm 8.7^{+}$ & $20.0 \pm 7.5$ & $17.2 \pm 6.5^{+}$ \\
\hline CI L. $\min ^{-1} \cdot \mathrm{m}^{-2}$ & $2.7 \pm 1.1$ & $3.1 \pm 1.4^{+}$ & $2.8 \pm 1.1$ & $3.1 \pm 1.0^{+}$ \\
\hline $\mathrm{Sv}, \mathrm{O}_{2} \%$ & $60.8 \pm 13.4$ & $68.5 \pm 12.8^{+}$ & $62.0 \pm 12.3$ & $66.0 \pm 10.8^{+, 5}$ \\
\hline
\end{tabular}

Data are presented as mean \pm SD. fC: cardiac frequency; $\bar{P}$ pa: mean pulmonary arterial pressure; $\bar{P}_{\text {sa: }}$ mean systemic arterial pressure; $R$ tp: total pulmonary resistance; $R$ sv: systemic vascular resistance; $\mathrm{Cl}$ : cardiac index; $\mathrm{Sv}_{1} \mathrm{O}_{2}$ : mixed venous oxygen saturation. ${ }^{\#}:$ : $50-200 \mu \mathrm{g} \cdot \mathrm{kg}^{-1} \cdot \mathrm{min}^{-1} ;{ }^{\bullet}: 5 \mu \mathrm{g} ;{ }^{+}: \mathrm{p}<0.05$ versus baseline; ${ }^{\text {s. }} p<0.05$ versus adenosine infusion.

nonresponders, the acute responders were younger $(22.6 \pm 9.1$ versus $34.5 \pm 11.8$ yrs for acute responders and nonresponders, respectively; $\mathrm{p}=0.008$ ), had a better WHO functional class (II/ III ratio of $9 / 1$ versus 26/38; $\mathrm{p}=0.002)$, a higher $S_{\mathrm{v}}, \mathrm{O}_{2}$ $(73.5 \pm 9.4 \%$ versus $60.7 \pm 12.0 \% ; \quad \mathrm{p}=0.008)$, lower $\bar{P}_{\mathrm{pa}}$ $(48.4 \pm 10.5$ versus $62.6 \pm 17.7 \mathrm{mmHg} ; \mathrm{p}=0.029)$, lower Pra $(3.1 \pm 1.9$ versus $6.8 \pm 5.6 \mathrm{mmHg} ; \mathrm{p}=0.001)$, and a lower serum ET-1 concentration $\left(0.6 \pm 0.2\right.$ versus $\left.1.0 \pm 0.6 \mathrm{fmol} \cdot \mathrm{L}^{-1} ; \mathrm{p}<0.001\right)$ (table 1).

\section{Adverse events}

$35(47.3 \%)$ out of the 74 patients experienced adverse events during adenosine infusion and only 39 patients were able to tolerate the maximum dosage. In contrast, only two $(2.7 \%)$ patients experienced adverse events during iloprost inhalation (table 3), and none required the test to be discontinued because of intolerable adverse effects.

\section{Follow-up}

All 10 acute responders to aerosolised iloprost (eight of whom also responded to infused adenosine) were treated with incremental high-dose CCB therapy (diltiazem: mean $\pm \mathrm{SD}$ (range) dosage $433 \pm 119(360-720) \mathrm{mg}^{\left.-\mathrm{day}^{-1}\right)}$. One acute responder was lost to follow-up, but the other nine patients were all re-evaluated for functional class and exercise capacity at 6-month intervals. In addition, their haemodynamic parameters were also reassessed after 12 months. The long-term follow-up results showed that the WHO functional class and Borg scale score were improved in all nine responders (table 4 ). The mean 6MWD was also significantly improved from $463 \pm 58$ to $583 \pm 61 \mathrm{~m}(\mathrm{p}<0.001)$. Moreover, when

\begin{tabular}{|c|c|c|}
\hline \multirow[t]{2}{*}{ TABLE 3} & \multirow[b]{2}{*}{ Adenosine } & \multirow[b]{2}{*}{ Iloprost } \\
\hline & & \\
\hline Subjects $n$ & 74 & 74 \\
\hline $\begin{array}{l}\text { Patients with adverse } \\
\text { events }\end{array}$ & $35(47.3)$ & $2(2.7)$ \\
\hline Increased cough & 0 & $1(1.4)$ \\
\hline Hypotension & $3(4.1)$ & $1(1.4)$ \\
\hline Flushing & $2(2.7)$ & 0 \\
\hline $\begin{array}{l}\text { Palpitations or short- } \\
\text { ness of breath }\end{array}$ & $27(36.5)$ & 0 \\
\hline Abdominal pain & $2(2.7)$ & 0 \\
\hline Pharyngeal pain & $1(1.4)$ & 0 \\
\hline $\begin{array}{l}\text { Other observed } \\
\text { adverse events }\end{array}$ & 0 & 0 \\
\hline
\end{tabular}

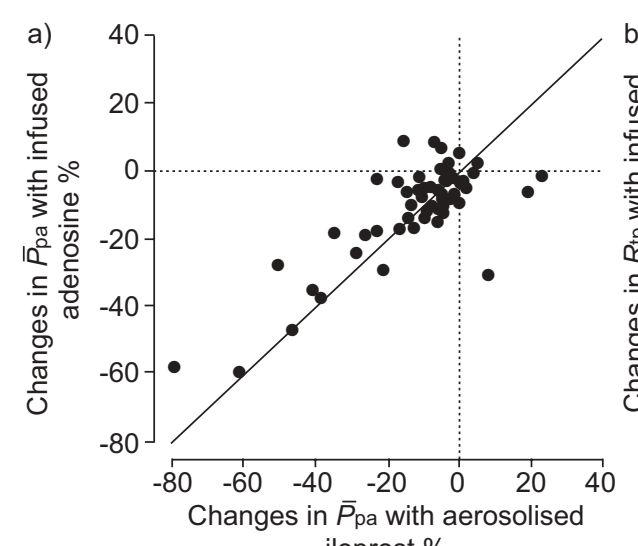
iloprost \%

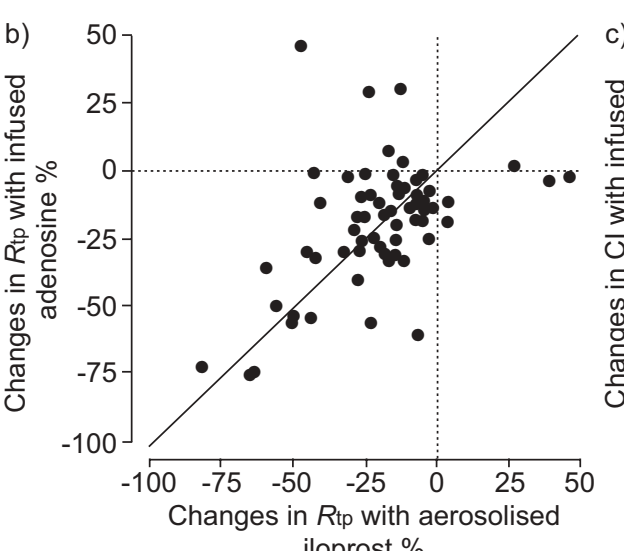

iloprost \%

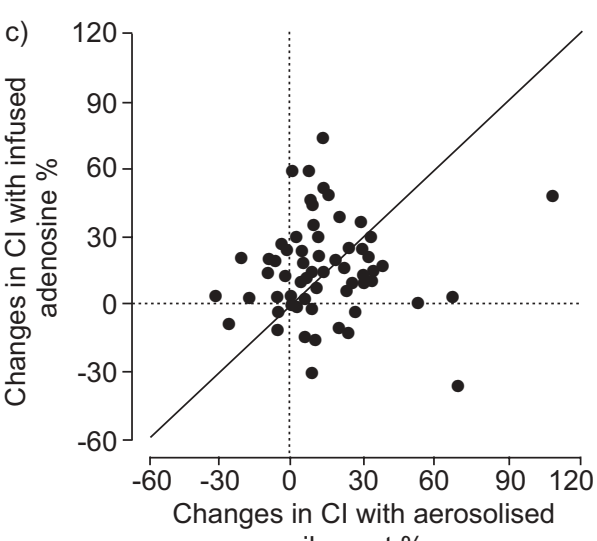

iloprost \%

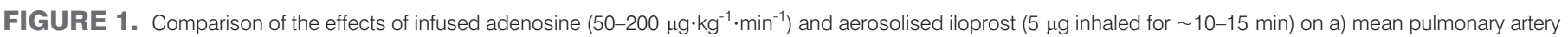

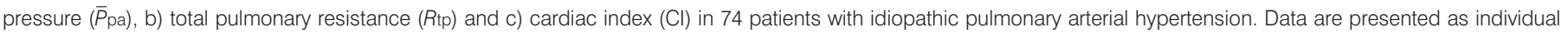

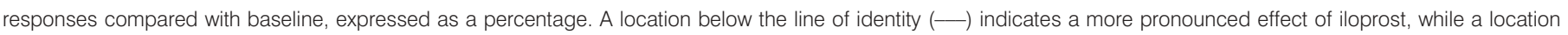
above the line of identity reflects a more pronounced effect of adenosine. $\cdots \cdots, 0 \%$ change. 


\begin{tabular}{|c|c|c|c|c|c|c|c|c|c|c|c|}
\hline TABLE 4 & $\begin{array}{l}\text { Basel } \\
\text { calciu }\end{array}$ & $\begin{array}{l}\text { ine and } \\
\text { im chanr }\end{array}$ & $\begin{array}{l}\text { long-term } \\
\text { nel blocke }\end{array}$ & $\begin{array}{l}\text { follow-up da } \\
r \text { therapy }\end{array}$ & a for nine & sponders & aerosolis & ilopros & fter $12 \mathrm{n}$ & ths of hig & dose \\
\hline \multirow[t]{2}{*}{ Responder } & \multirow[t]{2}{*}{ Sex } & \multirow[t]{2}{*}{ Age yrs } & \multirow[t]{2}{*}{ Weight kg } & \multirow{2}{*}{$\begin{array}{l}\text { Follow-up } \\
\text { time months }\end{array}$} & \multirow{2}{*}{$\begin{array}{l}\text { Dose of } \\
\text { diltiazem } \\
\mathrm{mg} \cdot \text { day }^{-1}\end{array}$} & \multicolumn{2}{|c|}{ WHO functional class } & \multicolumn{2}{|c|}{ 6MWD m } & \multicolumn{2}{|c|}{ Borg scale score } \\
\hline & & & & & & Baseline & Follow-up & Baseline & Follow-up & Baseline & Follow-up \\
\hline 1 & $\mathrm{~F}$ & 28 & 53 & 17 & 420 & 2 & 1 & 440 & 535 & 2 & 0 \\
\hline 3 & M & 34 & 57 & 14 & 360 & 2 & 1 & 362 & 585 & 3 & 1 \\
\hline 4 & $\mathrm{~F}$ & 20 & 63 & 20 & 360 & 2 & 1 & 440 & 570 & 3 & 0 \\
\hline 5 & $\mathrm{~F}$ & 24 & 56 & 14 & 480 & 2 & 1 & 510 & 577 & 2 & 0 \\
\hline 6 & $\mathrm{~F}$ & 48 & 67 & 15 & 480 & 3 & 2 & 450 & 506 & 2 & 1 \\
\hline 7 & $\mathrm{~F}$ & 13 & 39 & 21 & 360 & 2 & 1 & 420 & 632 & 1 & 0 \\
\hline 8 & $\mathrm{~F}$ & 9 & 21 & 20 & 720 & 2 & 1 & 560 & 645 & 1 & 0 \\
\hline
\end{tabular}

WHO: World Health Organization; 6MWD: 6 min walk distance; F: female; M: male. ${ }^{\#}$ : eight patients were also responders to infused adenosine.

re-evaluated by right heart catheterisation, the nine responders all had a decreased baseline $\bar{P}$ pa and pulmonary vascular resistance compared with their first assessment, and five had normal or near-normal haemodynamics $\left(\bar{P}_{\text {pa }}<30 \mathrm{mmHg}\right)$ (fig. 2).

\section{DISCUSSION}

This study is the first to verify the effectiveness and tolerability of aerosolised iloprost for identifying long-term responders to oral CCB therapy in patients with IPAH via acute vasoreactivity testing. Iloprost demonstrated comparable effects on haemodynamic variables to adenosine infusions and exhibited a similar capacity to identify those who would likely achieve sustained benefit from long-term CCB therapy. However, the

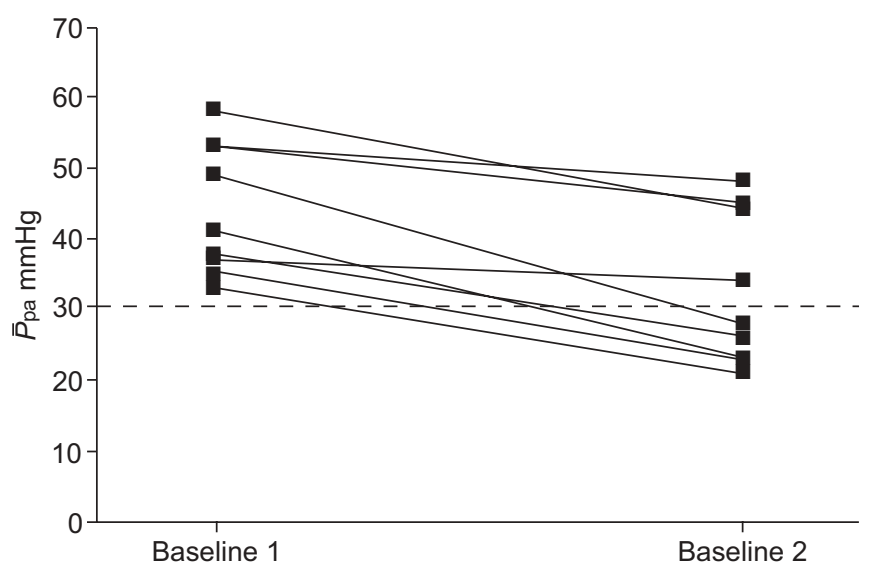

FIGURE 2. Changes in mean pulmonary artery pressure $\left(\bar{P}_{\mathrm{pa}}\right)$ between baseline 1 (first evaluation in our centres) and baseline 2 (re-evaluation after 12 months of high-dose calcium channel blocker (CCB) therapy) during right heart catheterisation in nine responders to aerosolised iloprost. After high-dose CCB treatment, haemodynamic parameters at baseline were improved in all nine patients, and five achieved normal or near-normal haemodynamics ( $\bar{P}$ pa $<30 \mathrm{mmHg} ;----)$. safety and tolerability of iloprost during acute vasoreactivity testing were superior to adenosine infusion. After long-term treatment with a CCB for 12 months, nine out of the 10 iloprost responders (one was lost to follow-up) had significantly improved clinical features and exercise capacity, and five had improved heart function (all WHO class I or II) and normal or near-normal haemodynamics $\left(\bar{P}_{\text {pa }}<30 \mathrm{mmHg}\right)$.

Adenosine is an endogenous vasodilator with a short half-life [17]. Central venous infusion of adenosine can be used as a "selective" pulmonary vasodilator as it is cleared from the blood in few seconds before it exerts a vasodilating effect in the systemic circulation [18]. Because of these properties, adenosine has become one of the three agents recommended in recent clinical practice guidelines to perform acute vasoreactivity testing $[3,4]$. As a new treatment option, iloprost has a relatively longer plasma half-life than adenosine (or epoprostenol), and has been shown to have favourable effects on pulmonary haemodynamics. As noted by PALEVSKY et al. [19] in 1990 and GALIÈ et al. [20] in 1995, the ideal screening agent should be a short-acting compound that is cleared rapidly from the body. The favourable pulmonary selectivity and improved tolerability of iloprost suggest that it may be a valuable screening agent to identify long-term responders to CCBs. While iloprost has been used for acute vasoreactivity testing in many pulmonary hypertension centres, this is the first study to show that $\sim 50 \%$ of acute responders to iloprost vasoreactivity testing may be long-term responders after 12 months. In our study, iloprost inhalation was as effective as adenosine in significantly decreasing $\bar{P}$ pa and Rtp, and increasing CI and $\mathrm{S}_{\mathrm{v}, \mathrm{O}_{2}}$. No patient manifested an acute vasodilator response to adenosine without also responding to iloprost.

Although aerosolised iloprost produced a statistically significant decrease in $R$ sv, the decrease in $\bar{P}_{\text {sa }}$ was only $\sim 2 \mathrm{mmHg}$, and only one patient experienced slight hypotension. The numbers of adverse events occurring with aerosolised iloprost during vasoreactivity testing were much fewer than those occurring with infused adenosine. Whereas $47.3 \%$ of patients experienced adverse events (mostly palpitations or shortness 
of breath) with adenosine, only $2.7 \%$ experienced adverse events with iloprost.

The recommended dosage of infused adenosine to acutely assess vasodilator responsiveness is $50 \mu \mathrm{g} \cdot \mathrm{kg}^{-1} \cdot \mathrm{min}^{-1}$, increased by $50 \mu \mathrm{g} \cdot \mathrm{kg}^{-1} \cdot \mathrm{min}^{-1}$ every $2 \mathrm{~min}$ to a maximum dose of 350 $500 \mu \mathrm{g} \cdot \mathrm{kg}^{-1} \cdot \mathrm{min}^{-1}[3,4]$. However, in this study, we found that the mean tolerated dose of infused adenosine was just $167 \pm 42 \mu \mathrm{g} \cdot \mathrm{kg}^{-1} \cdot \mathrm{min}^{-1}$, and only 39 out of the 74 patients were able to receive $200 \mu \mathrm{g} \cdot \mathrm{kg}^{-1} \cdot \mathrm{min}^{-1}$ without experiencing adverse effects. The mean dose of infused adenosine that achieved a maximal reduction in $\bar{P}_{\text {pa }}$ was $88 \pm 40 \mu \mathrm{g} \cdot \mathrm{kg}^{-1} \cdot \mathrm{min}^{-1}$, which is significantly lower than the recommended maximal dose. In addition, the dose that achieved a maximal reduction in $\bar{P}$ pa was much lower in responders than in nonresponders $(72 \pm 9$ versus $90 \pm 42 \mu \mathrm{g} \cdot \mathrm{kg}^{-1} \cdot \mathrm{min}^{-1}$, respectively; $\left.\mathrm{p}=0.004\right)$, and the dose in all responders was $<100 \mu \mathrm{g} \cdot \mathrm{kg}^{-1} \cdot \mathrm{min}^{-1}$. Thus, we believe that the dosage of infused adenosine recommended in recent guidelines is too high to assure its safety and tolerability for acute vasoreactivity testing. At least for Chinese patients, a dose ranging $50-200 \mu \mathrm{g} \cdot \mathrm{kg}^{-1} \cdot \mathrm{min}^{-1}$ appears high enough to evaluate acute pulmonary responsiveness.

Other than vasoreactivity testing, there are, at present, no valuable clinical or haemodynamic features that can be considered useful predictors for identifying patients who are likely to be acute responders [21-23]. However, in our study, younger patients were more likely to be acute responders. Younger patients may have less severe disease, as demonstrated by a higher proportion in WHO functional class II, a lower $\bar{P}_{\text {pa }}$ and $P$ ra, and a higher $S_{\mathrm{v}}, \mathrm{O}_{2}$. Interestingly, we also found that the ET-1 concentration in acute responders was profoundly lower than in nonresponders. These results may be explained by the strong correlation between ET-1 and the severity of PAH $[24,25]$.

Our study has several limitations. First, adenosine was always given before iloprost and, although we ensured that haemodynamic parameters had returned to baseline before iloprost was administered, we cannot fully exclude a conditioning or priming effect of pre-treatment with adenosine. Secondly, adenosine is not the most commonly used agent to perform acute vasoreactivity testing because of its lower selectivity for the pulmonary circulation in comparison with $\mathrm{NO}$ or epoprostenol. We were not able to compare iloprost with the latter agents as neither has been available in mainland China to date. Finally, the duration of follow-up may not have been long enough to fully confirm that those patients who responded acutely in the first evaluation were still long-term responders.

In conclusion, aerosolised iloprost can be effectively and safely used as a screening agent to identify long-term responders to oral CCB therapy in patients with IPAH. In comparison with adenosine infusion, iloprost is much better tolerated and has the potential to become a valuable new choice for vasoreactivity testing.

\section{ACKNOWLEDGEMENTS}

The authors wish to acknowledge R. Ronald (Singapore) for his editorial assistance in the preparation of this manuscript.

\section{REFERENCES}

1 Rich S, Kaufmann E, Levy PS. The effect of high doses of calcium-channel blockers on survival in primary pulmonary hypertension. N Engl J Med 1992; 327: 76-81.

2 Groves BM, Badesch DB, Turkevich D, et al. Correlation of acute prostacyclin response in primary (unexplained) pulmonary hypertension with efficacy of treatment with calcium channel blockers and survival. In: Weir KE, Hume JR, Reeves JT, eds. Ion Flux in Pulmonary Vascular Control. New York, Plenum, 1993; pp. 317-330.

3 Badesch DB, Abman SH, Ahearn GS, et al. Medical therapy for pulmonary arterial hypertension: ACCP evidencebased clinical practice guidelines. Chest 2004; 126: 35S-62S.

4 Galiè N, Torbicki A, Barst R, et al. Guidelines on diagnosis and treatment of pulmonary arterial hypertension.The Task Force on Diagnosis and Treatment of Pulmonary Arterial Hypertension of the European Society of Cardiology. Eur Heart J 2004; 25: 2243-2278.

5 Opitz CF, Wensel R, Bettmann M, et al. Assessment of the vasodilator response in primary pulmonary hypertension. Comparing prostacyclin and iloprost administered by either infusion or inhalation. Eur Heart J 2003; 24: 356-365.

6 Barst RJ, Rubin LJ, Long WA, et al. A comparison of continuous intravenous epoprostenol (prostacyclin) with conventional therapy for primary pulmonary hypertension. The Primary Pulmonary Hypertension Study Group. N Engl J Med 1996; 334: 296-302.

7 Schrader BJ, Inbar S, Kaufmann L, et al. Comparison of the effects of adenosine and nifedipine in pulmonary hypertension. J Am Coll Cardiol 1992; 19: 1060-1064.

8 Ricciardi MJ, Knight BP, Martinez FJ, et al. Inhaled nitric oxide in primary pulmonary hypertension: a safe and effective agent for predicting response to nifedipine. J Am Coll Cardiol 1998; 32: 1068-1073.

9 Sitbon $\mathrm{O}$, Humbert M, Jagot JL, et al. Inhaled nitric oxide as a screening agent for safely identifying responders to oral calcium-channel blockers in primary pulmonary hypertension. Eur Respir J 1998; 12: 265-270.

10 Badesch DB, McLaughlin VV, Delcroix M, et al. Prostanoid therapy for pulmonary arterial hypertension. J Am Coll Cardiol 2004; 43: Suppl. 12, 56S-61S.

11 Fullerton DA, Kirson LE, Jones SD, et al. Adenosine is a selective pulmonary vasodilator in cardiac surgical patients. Chest 1996; 109: 41-46.

12 Miller OI, Tang SF, Keech A, et al. Rebound pulmonary hypertension on withdrawal from inhaled nitric oxide. Lancet 1995; 346: 51-52.

13 Lavoie A, Hall JB, Olson DM, et al. Life-threatening effects of discontinuing inhaled nitric oxide in severe respiratory failure. Am J Respir Crit Care Med 1996; 153: 1985-1987.

14 Hoeper MM, Olschewski H, Ghofrani HA, et al. A comparison of the acute hemodynamic effects of inhaled nitric oxide and aerosolized iloprost in primary pulmonary hypertension. German PPH Study Group. J Am Coll Cardiol 2000; 35: 176-182. 
ILOPROST FOR PULMONARY VASODILATOR TESTING

Z-C. ING ET AL.

15 Gomberg-Maitland M, Olschewski H. Prostacyclin therapies for the treatment of pulmonary arterial hypertension. Eur Respir J 2008; 31: 891-901.

16 Hooper MM, Lee SH, Voswinckel R, et al. Complications of right heart catheterization procedures in patients with pulmonary hypertension in experienced centers. J Am Coll Cardio 2006; 48: 2546-2552.

17 Belardinelli L, Linden J, Benne RM. The cardiac effects of adenosine. Prog Cardiovasc Dis 1989; 32: 73-97.

18 Goldsmith DR, Wagstaff AJ. Inhaled iloprost: in primary pulmonary hypertension. Drugs 2004; 64: 763-773.

19 Palevsky HI, Long W, Crow J, et al. Prostacyclin and acetylcholine as screening agents for acute pulmonary vasodilator responsiveness in primary pulmonary hypertension. Circulation 1990; 82: 2018-2026.

20 Galiè N, Usia G, Passarelli P, et al. Role of pharmacologic tests in the treatment of primary pulmonary hypertension. Am J Cardio 1995; 75: 55A-62A.
21 Sitbon $\mathrm{O}$, Humbert $\mathrm{M}$, Jails $\mathrm{X}$, et al. Long-term response to calcium channel blockers in idiopathic pulmonary arterial hypertension. Circulation 2005; 111: 3105-3111.

22 Palevsky HI, Schloo BL, Petra GG, et al. Primary pulmonary hypertension: vascular structure, morphometry and responsiveness to vasodilator agents. Circulation 1989; 80: 1207-1221.

23 Raffy O, Azorian R, Brent F, et al. Clinical significance of the pulmonary vasodilator response during short-term infusion of prostacyclin in primary pulmonary hypertension. Circulation 1996; 93: 484-488.

24 Stewart DJ, Levy RD, Cernacek P, et al. Increased plasma endothelin-1 in pulmonary hypertension: marker or mediator of disease? Ann Intern Med 1991; 114: 464-469.

25 Rubin LJ, Badesch DB, Burst RJ, et al. Bosentan therapy for pulmonary arterial hypertension. N Engr J Med 2002; 346: 896-903.

1360

VOLUME 33 NUMBER 6

EUROPEAN RESPIRATORY JOURNAL 